\title{
REE patterns of garnets from diamonds and diamondiferous peridotites - geochemical signatures of the diamond source
}

\author{
Stachel, T. ${ }^{1}$, Viljoen, K.S. ${ }^{2}$, Harris, J.W. ${ }^{3}$, and Brey, G.P. ${ }^{1}$ \\ 1. Institut für Mineralogie, Universität Frankfurt, Senckenberganlage 28, 60054 Frankfurt. Germany, \\ 2. Anglo American Research Laboratories, PO Box 106, Crown Mines. 2025, South Africa \\ 3. Department of Geology \& Applied Geology, University of Glasgow, Glasgow G12 8QQ
}

Garnets from diamondiferous and barren peridotite xenoliths from the Roberts Victor kimberlite (Viljoen et al., 1994) and garnet inclusions in alluvial diamonds from the Birim deposits in Ghana (Stachel and Harris, 1997) were analysed for trace elements by secondary ion mass spectrometry (Cameca IMS $4 \mathrm{f}$ ion microprobe at Edinburgh University). Comparison of nodule garnets and garnet inclusions in diamonds reveals similar trace element patterns which are characterised by a non-transitional separation of the lherzolitic and the harzburgitic paragenesis. Lherzolitic garnets from both sources are depleted in LREE $\mathrm{N}_{\mathrm{N}}(\mathrm{N}$ for chondrite normalised) and have enriched and flat MREE $_{\mathrm{N}}$ and HREE $\mathrm{N}$ patterns (Fig. 1). Chondrite normalised patterns for harzburgitic garnets (Fig.2) are sinusoidal, with a peak within the $L_{R E E_{N}}$ around $\mathrm{Pr}$ and a trough within the MREE $\mathrm{N}_{\mathrm{N}}$ around Ho. The shape of the patterns is very similar for all samples but the depth of the trough and the actual concentrations vary widely. Similar sinusoidal patterns were previously described for sub-calcic garnets in heavy mineral concentrates from Southern African kimberlites (Shimizu and Richardson, 1987, Hoal et al., 1994) and for garnets in harzburgite xenoliths (Nixon et al., 1987). The clear separation between the lherzolitic and harzburgitic parageneses is also apparent in other trace elements, e.g. with $\mathrm{Ti}, \mathrm{Zr}$ and $\mathrm{Y}$ being higher in lherzolitic garnets and $\mathrm{Sr}$ being higher in harzburgitic garnets.

Experimental work (Bulatov et al., 1991, Canil and Wei, 1992) has shown that chromium rich garnets $\left(\mathrm{Cr}_{2} \mathrm{O}_{3}>4\right.$ wt.\%) cannot be explained as a residual phase of single stage melt extraction in the garnet stability field, but may originate as a metamorphic product of a harzburgitic residuum depleted by partial melting in the stability field of spinel peridotite. Therefore, $\mathrm{Cr}_{2} \mathrm{O}_{3}$ contents of more than $4 \mathrm{wt} \%$ indicate that harzburgitic and lherzolitic garnets from Roberts Victor (nodules) and Ghana (diamonds) had harzburgitic precursors which obtained their high $\mathrm{Cr} / \mathrm{Al}$ by depletion in the spinel stability field.

Enrichment and depletion of REE in peridotitic garnets can be better visualised if these garnets are normalised to a garnet derived from a primitive mantle. A high temperature sheared Iherzolite xenolith from Jagersfontein (J4 of Jagoutz and Spettel in Wolff-Boenisch, 1994) has a very primitive bulk and mineral chemistry and REE concentrations in garnet which closely match

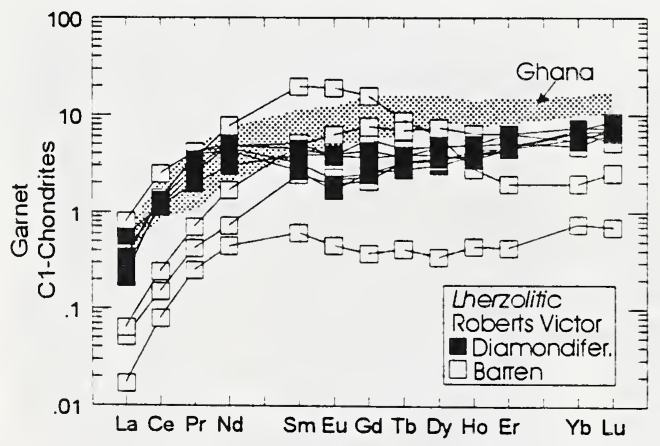

Fig. 1. Chondrite normalised REE concentrations in Iherzolitic garnets.

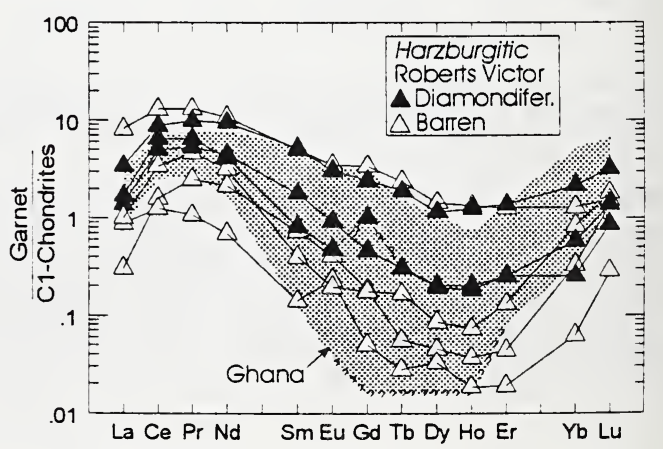

Fig. 2. Chondrite normalised REE concentrations in harzburgitic garnets. 
those calculated for garnets crystallised in a primitive mantle. Normalised to this garnet the lherzolitic garnets, despite their high chromium contents, have flat and only slightly depleted (xenoliths) to undepleted (inclusions) REE patterns (Fig. 3). This paradox requires a secondary enrichment event which introduced previously depleted major elements such as $\mathrm{Ca}$ and $\mathrm{Fe}$ and caused REE enrichment to a degree which erased the memory of the earlier depletion and, hence, resulted in patterns typical for an undepleted source. The REE patterns of harzburgitic garnets loose their sinusoidal shape (Fig. 4) and only show a trough in the MREE. This also indicates an evolution in at least two stages: (i) A melt extraction event that produced LREE depleted patterns and high $\mathrm{Cr}$ contents. The positive slope from Ho to Lu may be indicative of this stage and is particularly well preserved in inclusions in diamonds from Ghana, but is also apparent for Roberts Victor, where depletion seems to be less pronounced. Depleted MORB mantle from the Voykar Massif, Polar Urals (Sharma and Wasserburg, 1996) shows such steep, positive LREE-HREE slopes as indicated by the Ho to Lu "tail". Since orthopyroxene and spinel precursors could not effectively retain HREE in the residuum, such strong LREE/HREE fractionation implies depletion within the garnet stability field. In connection with the high $\mathrm{Cr}$ contents this indicates a source evolution during fractional decompression melting (MORB extraction) which started in the garnet stability field but continued into the spinel stability field. (ii) A metasomatic enrichment event reintroduced the previously depleted incompatible LREE and MREE with the degree of re-enrichment strongly declining from La to Dy.

Since high chromium contents in garnets from both parageneses document formation from residual harzburgite the key difference must be sought in the type and the extent of re-enrichment. For the Ghanaian inclusions the metasomatic re-enrichment seen in the lherzolitic paragenesis is consistent with infiltration of low volume alkaline melts whereas for the harzburgitic paragenesis sub-solidus equilibration temperatures and extreme trace element fractionation exclude melt involvement and suggest enrichment by percolating methane rich fluids (Stachel and Harris, 1997). Such fluids may have evolved during chromatographic column type interaction with garnet bearing peridotitic wall rocks which preferentially extracted the more compatible HREE. Different origins for lherzolitic and harzburgitic inclusions in southern African diamonds have also been suggested by Griffin et al. (1992), who also concluded that lherzolitic diamonds probably formed in the presence of a melt. Because there is a very close similarity in the REE patterns between the garnet inclusions from Ghana and the garnets from xenoliths from Roberts Victor we conclude that their lherzolitic and harzburgitic parageneses also have similar origins. However, by relating diamond formation and metasomatic source enrichment we do not imply that the diamond formation event was the first and only metasomatic event affecting the harzburgitic diamond source region. On the contrary, Richardson et al. (1984) report low ${ }^{143} \mathrm{Nd} /{ }^{144} \mathrm{Nd}$ ratios for garnet inclusions in diamond

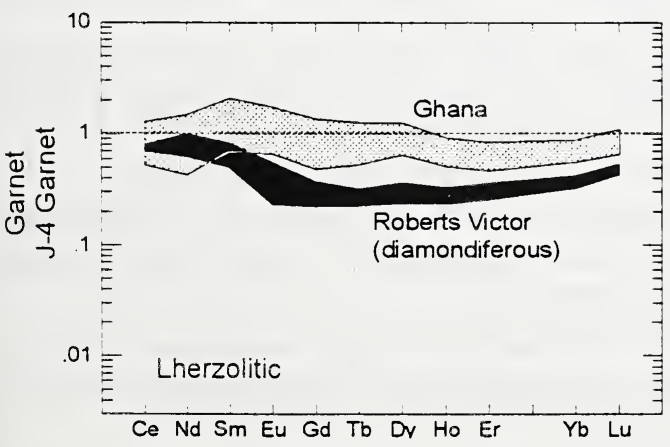

Fig. 3. REE concentrations in Iherzolitic garnets (diamondiferous xenoliths and inclusions) normalised to $\mathrm{J} 4$ garnet.

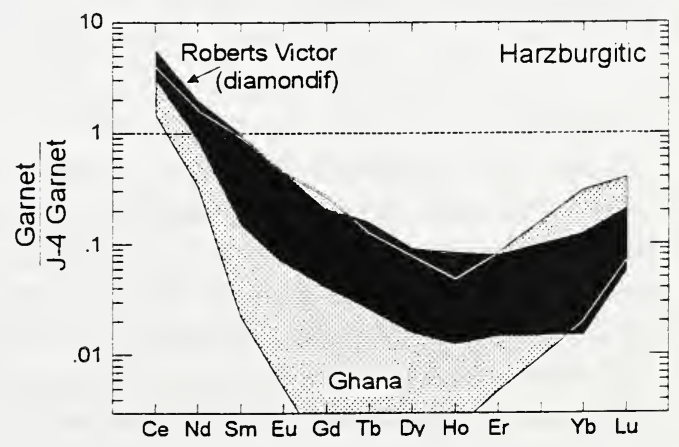

Fig. 4. REE concentrations in harzburgitic garnets (diamondiferous xenoliths and inclusions). 
with ${ }^{87} \mathrm{Sr} /{ }^{86} \mathrm{Sr}$ ratios that are unsupported by the low intrinsic $\mathrm{Rb}$ contents. This evidence indicates metasomatic enrichment of the host rock long before diamond formation. However, the agent responsible for this ancient enrichment is difficult to assess: The chemical evidence of low $\mathrm{Ti}, \mathrm{Y}, \mathrm{Hf}$ and $\mathrm{Zr}$ and petrographical characteristics (e.g. hydrous mineral inclusions are generally absent in diamond) of the harzburgitic diamond source are not indicative of previous metasomatism by kimberlitic-lamproitic or hydrous basaltic melts. The virtual absence of carbonate minerals as inclusions excludes diamond precipitation from carbonatitic melts. Previous source enrichment by carbonatites, however, is feasible because of their $\mathrm{Sr}$ and LREE enriched and $\mathrm{Ti}$ and $\mathrm{Zr}$ depleted characteristics (Griffin et al., 1992).

The observed similarity of the trace element composition of inclusion and nodule garnets shows that inclusions in diamond reflect physical and chemical conditions which are also recorded in the surrounding garnet peridotite. This implies that inclusions in diamonds do not just represent a transient picture in the development of the subcratonic mantle but that they yield accurate information on its equilibrium state. Nevertheless and possibly to our advantage, multiple inclusions in diamonds may reflect pathways in the evolution of the mantle.

\section{References}

Bulatov, V., Brey, G.P., and Foley, S.F., 1991, Origin of low-Ca, high-Cr garnets by recrystallization of low-pressure harzburgites: Fifth International Kimberlite Conference, Araxá (Brazil), Extended Abstracts, CPRM Spec. Publ., v. 2/91, p. 29-31.

Canil, D., and Wei, K.J., 1992, Constraints on the origin of mantle-derived low Ca garnets: Contrib. Mineral. Petrol., v. 109, p. 421-430.

Griffin, W.L., Gurney, J.J., and Ryan, C.G., 1992, Variations in trapping temperatures and trace elements in peridotite-suite inclusions from African diamonds: evidence for two inclusion suites, and implications for lithosphere stratigraphy: Contrib. Mineral. Petrol., v. 110, p. 1-15.

Hoal, K.E.O., Hoal, B.G., Erlank, A.J., and Shimizu, N., 1994, Metasomatism of the mantle lithosphere recorded by rare earth elements in garnets: Earth Planet. Sci. Lett., v. 126, p. 303-313.

Nixon, P.H., van Calsteren, P.W.C., Boyd, F.R., and Hawkesworth, C.J., 1987, Harzburgites with garnets of diamond facies from Southern African kimberlites, in Nixon, P.H., ed., Mantle Xenoliths: Chichester, J. Wiley \& Sons, pp. 523-533.

Richardson, S.H., Gurney, J.J., Erlank, A.J., and Harris, J.W., 1984, Origin of diamonds from old continental mantle: Nature, v. 310, p. 198-202.

Sharma, M., and Wasserburg, G.J., 1996, The neodymium isotopic compositions and rare earth patterns in highly depleted ultramafic rocks: Geochim. Cosmochim. Acta, v. 60, p. 4537-4550.

Shimizu, N., and Richardson, S.H., 1987, Trace element abundance patterns of garnet inclusions in peridotite-suite diamonds: Geochim. Cosmochim. Acta, v. 51, p. 755-758.

Stachel, T., and Harris, J.W., 1997, Diamond precipitation and mantle metasomatism - evidence from the trace element chemistry of silicate inclusions in diamonds from Akwatia, Ghana: Contrib. Mineral. Petrol, v. 128, p. 143-154.

Viljoen, K.S., Robinson, D.N., Swash, P.M., Griffin, W.L., Otter, M.L., Ryan, C.G., and Win, T.T., 1994, Diamond- and graphite-bearing peridotite xenoliths from the Roberts Victor Kimberlite, South Africa, in Meyer, H.O.A., and Leonardos, O.H., eds., Kimberlites, related rocks and mantle xenoliths: Brasilia, CPRM Spec. Publ., v. 1/A Jan/94, p. 285-303.

Wolff-Boenisch, B., 1994, Aufbau der Analytik zur Messung der Osmium-Isotopie sowie die Strontium-, Neodym- und Osmium-Systematik eines Hoch-Temperatur-Granat-Lherzoliths (J4) von Jagersfontein (Südafrika): Mainz (Germany), Dipl. Thesis. 